\title{
Chinese Rationale for Free Trade Agreements
}

\author{
Asst. Prof. Dr. Farrukh Kayani (COMSATS Institute of Information Technology, Pakistan) \\ Prof. Dr. Zhongxiu Zhao (University of International Business and Economics, China)
}

\begin{abstract}
In East Asia economic regionalism and Free Trade Agreements (FTAs) are proliferating at tremendous pace despite being the latecomer as compared to Americas and Europe. Proliferation of FTAs in East Asia started to spread after the Asian financial crisis of 1997. The East Asian economies were dissatisfied with the way the IMF handled the crisis, particularly in Thailand and Indonesia. Presently, about over 100 FTAs are at various stages of development in East Asia. China is also actively engaged in FTAs like the other East Asian neighboring countries for achieving multiple objectives. In this paper we analyzed the detailed reasons that why China is pursuing FTAs? Furthermore, it is said that FTAs may jeopardize the multilateral trading system. As FTAs undermine the WTO policy of maintaining a liberal, non discriminatory and multilateral trading system by supporting the government interventions and prudential controls. Thus we would also explore that whether FTAs are building or stumbling blocks?
\end{abstract}

JEL code: F15

\section{Introduction:}

East Asia is a latecomer in the move towards FTAs as compared to the Americas, Europe, and Africa. FTAs are proliferating at tremendous pace in East Asia. Proliferation of FTAs in East Asia started to spread after the Asian financial crisis of 1997. The East Asian economies were dissatisfied with the way the IMF handled the crisis, particularly in Thailand and Indonesia. After the Asian crisis, China, Japan, and South Korea started pursuing FTAs and in a short period of time East Asia became the most dynamic region in terms of FTAs negotiated and concluded. Presently, about over 100 FTAs are at various stages of development in East Asia.

There are varied reasons why countries join FTAs. Some of these are political and relate to factors such as geographic proximity, cultural affinity, shared political objectives, economic ties, and shared historical bonds. For some countries this is to do with collective action problems linked to security or economic development. More concretely, creating economies of scale and providing an opportunity for learning-by-doing to foster competitiveness is a common thread that runs through almost all RTA arrangements (Draper and Qobo 2007).

It is important to realize that China is changing rapidly in its approach to regional economic cooperation as highlighted by Masahiro Kawai .The payoff of such a policy appears high for China because its economic growth depends on the favorable prospect of the regional economies, political stability, and peace and security. Its FTA initiative with ASEAN is one important sign of its willingness to deepen its economic, as well as political, relationship with its Southeast Asian neighbors (Kawai 2008).

\section{Free Trade Agreements (FTAs) and the WTO:}

Until in 1980s, FTAs and Regional Trade Agreements (RTAs) have been mostly limited to Western Europe and regionalism has been mainly regarded as a European concept. But, since 1990s FTAs are proliferating in every part of the world at tremendous pace. Actually under FTAs the member countries agree to abolish their tariffs on almost all trade among themselves while they retain trade barriers with nonmember country outside arrangement. FTAs aim to secure the property rights of foreign investors, institutionalize their participation in the host economy, and assure them of the government's commitment to a liberal economic policy. Such agreements help to create a more favorable environment for foreign investment.

FTAs are legally binding arrangements between two or more countries, in which these countries give each other preferential treatment in trade that eliminates trade protection among members but each member keep its own tariff structure in trade with third countries (Tekce and Acar 2008). FTAs and RTAs are allowed to exist and to operate under the multilateral trading system. WTO rules governing RTAs include GATT Article XXIV on trade in goods, GATS Article V on trade in services and the Enabling Clause on South-South (preferential) agreements.

On the positive side, FTAs and RTAs enable participating countries to move closer and quicker to freer trade with stronger disciplines over a wider range of goods and services. In this way, RTAs could be building blocks for a more open and liberal MTS. On the negative side, RTAs may result in inward-looking, discriminatory and protectionist trading entities competing for spheres of influence and becoming self-contained fortresses (Mashayekhi, Puri and Ito 2005).

Majority of Economists declare FTAs as building blocks. According to their views FTAs are facilitating trade liberalization. But they also call for a strong need of addressing the harmful effects of FTAs on the third countries in the form of discriminatory tariffs. FTAs are building blocks for multilateral trade. FTAs strengthen 
the trade relations among partner countries and make it easier to build alliances for WTO reforms in areas of common interest (Schott 2004).Opponents however view FTAs damaging multilateral trading system. One argument on the possibility holds as within-block trade increases under preferential trading agreements, countries within the system become more likely to raise barriers against parties outside the agreement. (Lu 2003).

Regarding the supremacy of the WTO over FTAs and RTAs, the constituent treaties of many new-generation RTAs clearly state that these need to be consistent with WTO rules. This indicates that future RTAs would be built on the WTO, seeking to maintain compatibility with its disciplines. Thus constitute building blocks for the new multilateralism ushered in by the WTO. Regional trade agreements can play an important role in promoting the liberalization and expansion of trade and in fostering development. (Mashayekhi, Puri and Ito 2005).

\begin{tabular}{|c|c|c|c|}
\hline Year & Venue/Name & Subjects Discussed & Countries Participated \\
\hline 1947 & Geneva & Tariffs & 23 \\
\hline 1949 & Annecy & Tariffs & 13 \\
\hline 1951 & Torquay & Tariffs & 38 \\
\hline 1956 & Geneva & Tariffs & 26 \\
\hline $1960-1961$ & Geneva (Dillon Round) & Tariffs & 26 \\
\hline $1964-1967$ & Geneva (Kennedy Round) & Tariffs and Antidumping Measures & 62 \\
\hline $1973-1979$ & Geneva (Tokyo Round) & $\begin{array}{l}\text { Tariffs, non-tariff measures } \\
\text { "framework" agreements }\end{array}$ & 102 \\
\hline 1986-1994 & Geneva (Uruguay Round) & $\begin{array}{l}\text { Tariffs, non-tariff measures, rules, } \\
\text { services, intellectual property, dispute } \\
\text { settlement, textiles, agriculture, } \\
\text { creation of WTO, etc }\end{array}$ & 123 \\
\hline
\end{tabular}

Table 1. The Trade Rounds under GATT (1947-1994) Source: WTO

The basic objective of WTO rules is to promote greater integration of the world economy by encouraging countries to pursue 'open and liberal policies'. WTO came into being on January 1, 1995 after the completion of Uruguay Round of Trade Talks (1986-1994). WTO replaced the General Agreement on Trade and Tariff (GATT). GATT was signed in 1947 at the end of Bretton Woods meetings as the countries were interested to recover from the negative effects of World War II. The main aim was "reduction in tariffs and other international trade barriers". The GATT continued operating for about fifty years with the purpose of arranging rules for international trade of goods and diminishing tariffs and quotas. The Uruguay Round also contributed to the package of rules related to trade in services, relevant aspects of intellectual property, dispute settlement, and trade policy reviews. About 60 agreements and separate commitments were covered within the set of Uruguay Round negotiations (Tekce and Acar 2008).

\section{Why countries prefer FTAs over Multilateralism?}

Under FTAs negotiations among a limited number of "like-minded" countries reach to an agreement in a fast and speedy manner. Further with fewer participants, calculations of costs and benefits on RTAs can be made with less difficulty. The countries prefer FTAs as compared to multilateral trade liberalization because FTAs are faster and require less time than trade liberalization under the WTO. The Uruguay round, which was the last round of multilateral trade negotiations held under GATT, was initially scheduled to be completed in four years, but it actually took nearly eight years, almost twice as long as projected. Further he stated that FTAs would accelerate the multilateral trade liberalization of WTO. There is the view that, as FTAs promote liberalization, the expansion of FTAs will actually facilitate trade liberalization on a global scale (Urata 2002).

The potential benefits of RTAs are now well understood. There are three reasons that why countries favor bilateral or regional trade strategies over multilateralism? First, countries may hope to maximize their benefits through so-called first-mover advantages. That is, they focus on the gains they could obtain from signing an agreement with a large trading partner before competing countries do so. Second, countries may seek to guarantee permanent access to particular markets. Third, a bilateral agreement may be used as leverage to facilitate domestic reforms, particularly in areas that are not dealt with multilaterally, such as investment, competition, and environmental and labor standards (Mensbrugghe, Newfarmer and Pierola 2006).

\section{China and Free Trade Agreements:}

East Asia is a latecomer in the move towards FTAs as compared to the Americas, Europe, and Africa. FTAs are proliferating at tremendous pace in East Asia. Proliferation of FTAs in East Asia started to spread after the Asian financial crisis of 1997. The East Asian economies were dissatisfied with the way the IMF handled the crisis, particularly in Thailand and Indonesia (Kawai 2005). The ineffective rescue policies from the IMF and also from the lack of interest from North America and the EU as a during the damaging Asian crisis in 1997 as a reason of 
FTAs . The volatile international capital market that did not have proper prudential controls(Van Hoa 2002). Thus, after the Asian crisis, China, Japan, and South Korea started pursuing FTAs and in a short period of time East Asia became the most dynamic region in terms of FTAs negotiated and concluded.

The FTA of China with Hong Kong in 2004 was considered as a "gift" from China to Hong Kong. The FTA of China with Chile in 2005 is both economically and strategically important for China. China views FTA with Chile as a bridge between Asia and Latin America. The agreement is strengthening ties between the world's largest copper producer and the world's largest copper consumer and is also expected to provide a big boost to Chile's fruit exports (Zhang, Zhang and Fung 2007).

\begin{tabular}{|c|c|c|}
\hline Year & FTA & Details of the Agreements \\
\hline 2002 & Asia Pacific Trade Agreement & Preferential tariff arrangement. \\
\hline 2004 & $\begin{array}{l}\text { Mainland and Hong Kong Closer } \\
\text { Economic Partnership Arrangement }\end{array}$ & $\begin{array}{l}\text { Free trade agreement on goods and } \\
\text { services. }\end{array}$ \\
\hline 2004 & $\begin{array}{l}\text { Mainland and Macao Closer } \\
\text { Economic Partnership Arrangement }\end{array}$ & $\begin{array}{l}\text { Free trade agreement on goods } \\
\text { and services. }\end{array}$ \\
\hline $\begin{array}{l}2005,2007 \text { and } 2009 \text { for goods, } \\
\text { services \& investment } \\
\text { agreements respectively. }\end{array}$ & $\begin{array}{l}\text { Framework Agreement on } \\
\text { Comprehensive Economic Co- } \\
\text { operation between ASEAN and the } \\
\text { People's Republic of China. }\end{array}$ & $\begin{array}{l}\text { Establishes the ASEAN-China Free } \\
\text { Trade Area (ACFTA). }\end{array}$ \\
\hline 2006 & China-Chile FTA & $\begin{array}{l}\text { China agreed to reduce tariff on } 92 \% \\
\text { of Chilean exports. }\end{array}$ \\
\hline $\begin{array}{l}2007 \text { for goods and } 2009 \text { for } \\
\text { services }\end{array}$ & China-Pakistan FTA & $\begin{array}{l}\text { China agreed to eliminate tariffs on } \\
35.5 \% \text { of tariff lines within three } \\
\text { years and reduce tariffs on another } \\
48.5 \% \text { within five years. }\end{array}$ \\
\hline 2008 & China-New Zealand FTA & $\begin{array}{l}\text { China agreed to remove tariffs on } \\
96 \% \text { of New Zealand exports by } \\
2019\end{array}$ \\
\hline 2008 & China-Singapore FTA & $\begin{array}{l}\text { China agreed to remove tariffs on } \\
85 \% \text { of Singapore's exports to China } \\
\text { by } 2010 \text {. }\end{array}$ \\
\hline 2009 & China-Peru FTA & $\begin{array}{l}\text { To eliminate tariffs on } 90 \% \text { of all } \\
\text { trade items within } 16 \text { years. }\end{array}$ \\
\hline
\end{tabular}

Table 2. Free Trade Agreements of China Source: WTO Regional Trade Agreements Information System and Chinese Ministry of Commerce.

The People's Republic of China is also negotiating free trade agreements with Australia, the GCC, Saudi Arabia and Iceland, Norway, South Africa, Iceland, Costa Rica, the Southern African Customs Union (which includes Botswana, Lesotho, Namibia, and Swaziland). The PRC-New Zealand FTA is signed in 2008. The FTA of China with New Zealand is the first FTA of China with any industrialized country. The FTA between China and Saudi Arabia was proposed in 2006. China is interested in stronger ties with Saudi Arabia. Actually Saudi Arabia is the biggest exporter of oil and China has strong growing demands of energy. The PRC has also suggested a Northeast Asian FTA among the three nations in Northeast Asia (PRC, Japan, and Korea), as well as an East Asia-wide FTA for ASEAN+3 countries (the ten ASEAN members, PRC, Japan, and Korea). The ASEAN +3 process began when the leaders of Japan, China and Korea were invited to the informal ASEAN Leaders meeting in December 1997, in the midst of the Asian financial crisis.

China has numerous goals in signing FTAs like obtaining market status, access to important raw materials, solidifying its relations inside and beyond the East Asia and to gain improved market access for its exports. One immediate concern is to use them to obtain market status recognition and relief from being subject to special safeguards. A second motive is to secure access to important raw materials - many of are major suppliers of minerals (Chile-copper, Australia -- iron-ore and uranium, and the countries GCC - oil). A third is to solidify its relations and influence both inside and beyond the East Asian region. Individual agreements are also used to achieve specific goals. For example, the Hong Kong and Macao agreements help underscore the privileged relationship between the Mainland and these economies (Lawrence 2006).

FTAs can help achieve deeper economic integration. Integration measures have extended their reach beyond traditional free trade in goods to a number of domestic regulatory sphere including services, investment and intellectual property rights, to deepen the integration among partner countries. China is interested in FTAs as they generate the greater trade and FDI among the members. FTAs between FDI source and recipient economies would allow the latter to obtain advanced technologies, realize external economies, promote trade, industrialization, employment and economic growth (Kawai and Wignarajal 2007). 


\section{Conclusion:}

China is pursuing FTAs in order to achieve deeper penetration with trading partners on formal basis. As FTAs help in expanding trade and FDI activities through further elimination of cross-border impediments, harmonization of various rules, standards, and procedures. FTAs help Chinese firms to obtain better services, raw material and equipment at lower cost. Most importantly, FTAs create economic benefits for china like upgrading of technology, productivity and management practices. But the biggest challenge for Chinese trade policy would be to maintain the balance between FTAs and WTO liberalization framework. Furthermore, the FTAs are appearing to be as building blocks as they are facilitating trade liberalization but there is also a strong need of addressing the harmful effects of FTAs on third countries in the form of discriminatory tariffs.

\section{References}

- Bhagwati, J and A. Panagariya, 1996, "Preferential Trading Areas and Multilateralism: Strangers, Friends, or Foes?" in J. Bhagwati and A. Panagariya, eds. The Economics of Preferential Trade Agreements. Washington, DC: AEI Press.

- $\quad$ Draper Peter and Qobo Mzukisi, 2007, "Rabbits Caught in the Headlights? Africa and the "Multilateralizing Regionalism" Paradigm" Paper presented at the Conference on Multilateralizing Regionalism, Sponsored and organized by WTO - HEI, 10-12 September 2007 Geneva, Switzerland.

- Kawai Masahiro and Wignaraja1 Ganeshan, “ASEAN+3 or ASEAN+6: Which Way Forward?” Paper presented at the Conference on Multilateralising Regionalism, Sponsored and organized by WTO - HEI, 1012 September 2007 Geneva, Switzerland.

- Lu Fung, 2003, "Free Trade Area: Awakening regionalism in East Asia" China Center for Economic Research at Peking University, Working Paper Series No. E 2003010.

- M, Kawai, 2005, "East Asian Economic Regionalism: Progress and Challenges”, Journal of Asian Economics.

- Mashayekhi Mina, Puri Lakshmi and Itol Taisuke, 2005, "Multilateralism and Regionalism: The New Interface", United Nations Conference on Trade and Development.

- Mensbrugghe Dominique van der, Newfarmer Richard and Denisse Pierola Martha, 2006, "Regionalism vs. Multilateralism?" Trade, Doha, and Development: A Window into the Issues, The World Bank, Trade Department.

- Schott, JJ, 2004, "Free trade agreements: boon or bane of the world trading system" Free trade agreements: US strategies and priorities, 2004 - books.google.com

- Tekce Mahmut and Acar Cevil, 2008 "From Multilateralism to Bilateralism: The evolution of global trade policies", Marmara Universitesi.

- Urata, Shujiro, 2002, "Globalization and the Growth in Free Trade Agreements", Asia-Pacific Review, Vol. 9, No. 1, 2002.

- Van Hoa, Tran, 2002, "Korea, China and Japan: Their Trade with the World and Its Impact on New Asian Regionalism ASEAN+3”, Working Paper Series 2002, Department of Economics University of Wollongong.

- WTO, 2007b, Understanding the World Trade Organization, http:// www.wto.org/english/the wto_e/whatis_e/tif_e/understanding_e.pdf

- Z. Lawrence Robert, 2006, “China and the Multilateral Trading System”, Faculty Research Working Paper Series, RWP06-045, John F. Kennedy School of Government - Harvard University.

- Zhang, Yanying, Zhang Guiyan and Fung H, 2007, “The Prospects for China's Free Trade Agreements” The Chinese Economy, vol.40, no.2, pp.5-35 